\title{
Maintenance and breeding of Thrichomys (Trouessart, 1880) (Rodentia: Echimyidae) in captivity
}

\author{
Bernardo Rodrigues Teixeira/**, André Luiz R Roque/*, Simone Cristina Barreiros- \\ Gómez, Pavel Mikhailovitch Borodin/***, Ana Maria Jansen*, Paulo Sérgio D’Andrea/+
}

\begin{abstract}
Laboratório de Biologia e Controle da Esquistossomose, Departamento de Medicina Tropical *Laboratório de Tripanossomatídeos, Departamento de Protozoologia, Instituto Oswaldo Cruz-Fiocruz, Av. Brasil 4365, 21040-900 Rio de Janeiro, RJ, Brasil **Programa de Pós-Graduação em Zoologia, Museu Nacional/UFRJ, Rio de Janeiro, RJ, Brasil ***Institute of Cytology and Genetics, Novosibirsk 630090, Russia
\end{abstract}

South American histricognath rodents Thrichomys apereoides laurentius and Thrichomys pachyurus are natural hosts of Trypanosoma cruzi, agent of Chagas disease. We established breeding colonies of these species to serve as experimental models in various parasitological studies. Both species of Thrichomys have all the requirements necessary to become excellent laboratory models: they can be easily maintained in the standard laboratory conditions and breed throughout the year and they do not have any special dietary demands and can be fed by standard food pellets designed for laboratory mice. Both species produce precocious offspring that have their eyes and ears open, teeth erupted, fur well developed, and can eat solid food in the first week of life. T. a. laurentius has larger litter sizes and lower body masses at birth and weaning than T. pachyurus. Moreover, females of T. a. laurentius reach puberty earlier and with lower body mass than $\mathrm{T}$. pachyurus.

Key words: breeding - reproduction - development - Thrichomys

Bio-medical research is critically dependent on availability of adequate animal models. Progress in understanding of fundamental principles of physiology, endocrinology, development, reproductive and behavioral biology of mammals would be impossible without the use of various strains of mice, rats, hamsters, and other now common laboratory species. Studies in these model animals have made possible breakthroughs in treatment of many hereditary and infectious human diseases (Kumar et al. 2002, Belal et al. 2004, Bogdanovich et al. 2004, Garzoni et al. 2004). However, studies of the biology of many parasitic diseases lack appropriate animal models. These diseases involve very species-specific host-parasite interactions, which can not be studied on common models such as mice, rats, and hamsters. We are in great need of new models for studies of natural cycles of transmission of parasitic diseases. Recently, some of these models using wild small mammals have been successfully developed (D'Andrea et al. 1996, Hingst et al. 1998, Gonzalez \& Claramunt 2000, Magalhães-Santos et al. 2004).

In this paper we report our results in captive maintenance and breeding of two species of South American rodent, the punaré: Thrichomys (Trouessart, 1880) (Histricognathi: Echimyidae). These species are potentially important models for studies of the transmission of Chagas disease since several species of this genus have been shown to be natural reservoirs of its causitive protozooan agent Trypanosoma cruzi (Chagas, 1909)

Financial suport: IOC-Fiocruz, Papes-Fiocruz, Ibama, Faperj, $\mathrm{CNPq}$

+Corresponding author. E-mail: dandrea@ioc.fiocruz.br

Received 25 January 2005

Accepted 6 September 2005
(Herrera et al. 2004b, 2005). They are also involved in the transmission cycle of T. evansi (Steel, 1885), an agent of neurological disease affecting horses and some wild animals (Herrera et al. 2004a).

The presence of histricognath rodents in South America dates to at least 35 million years before the present, making them very ancient potential hosts of $T$. cruzi. Recently a strong association of the genotype TCII of $T$. cruzi with histricognath rodents has been postulated (Briones et al. 1999). Thus, parasitological studies using captive breed colonies of Thrichomys may clarify many still unknown aspects of the interaction of T. cruzi with their natural mammal hosts.

Species of Thrichomys have been found in various biomes of Brazil: savannahs ("cerrado"), white shrub ("caatinga"), and marshland ("pantanal") (Neiva \& Penna 1916, Alho 1982, Streilen 1982). Punarés often invade peri-domestic area and may play an important role in the transmission of Chagas disease (Herrera et al. 2005). Taxonomic status of local populations of Thrichomys is still a matter under discussion. Within the genus Thri-chomys, Bonvicino et al. (2002) and Pessôa et al. (2004) recognize T. pachyurus (Wagner, 1845) from Western Brazil (Mato Grosso do Sul and north of São Paulo); T. ape-reoides apereoides (Lund, 1839) from the west of Minas Gerais to Goiás; and T. a. laurentius (Thomas, 1904) from Piauí, Ceará and Pernambuco, among others. In our study we used T. pachyurus from Mato Grosso do Sul and T. $a$. laurentius from Piauí.

\section{MATERIALS AND METHODS}

The colony of $T$. a. laurentius was derived from 9 males and 38 females captured in the National Park Serra da Capivara and surroundings in southeastern Piauí (Caatinga biome). T. pachyurus colony was derived from 9 males and 34 females captured in municipality of Corumbá, in southwestern Mato Grosso do Sul (Pantanal biome). 
The wild caught animals were screened for trypanosomes, hantaviruses, and rickettsia and were treated with Ivermectin and anti-flea talcum to remove helminths and ectoparasites. They were kept in a quarantine building for 40 days and then transferred to the animal house of the Department of Tropical Medicine, of the Oswaldo Cruz Institute, Rio de Janeiro, where they were kept under conventional conditions (temperature $22-26^{\circ} \mathrm{C}$, natural daylight). The animals were marked by individual sub-cutaneous microchip (Trovan ${ }^{\circledR}$, Aeg \& Telefunken Electronics, Nürnberg, Germany).

Single animals were housed in 41 - by 34 - by $17 \mathrm{~cm}$ polypropylene cages. The breeding pairs and lactating females were housed in 66- by $57-$ by $23 \mathrm{~cm}$ cages, with a sawdust substrate. The cages were cleaned once a week. Water and food was provided ad libitum. The diet consists of NUVILAB CR1 mouse pellets (Nuvital Nutrients S.A., Colombo/PR, Brazil). No fresh food supplements were used.

Usually breeding pairs were kept together for 15 days. To estimate gestation time we kept breeding pairs together for only one day. The mated females were examined daily for signs of birth. Litter size, sex, ratio, and body mass at birth were determined within $24 \mathrm{~h}$ after parturition. The offspring were weaned on day 21 according to Roberts et al. (1988). Female sexual maturation was operationally defined as the weight and the age at vagina opening, according to other studies (D'Andrea et al. 1996).

All procedures followed protocols licensed by the Committees of Biosafety and Bioethics of the Oswaldo Cruz Institute.

We used the student's $t$ test to compare litter size and sexual maturation times between species, and birth and weaning masses, between species and sexes. We used Chi square to compare sex ratio at birth, postnatal mortality and breeding success.

\section{RESULTS}

Handling - The animals of both species do not show obvious signs of distress in laboratory conditions, although we found that specimens of $T$. pachyurus were more excitable than those of $T$. a. laurentius. A special precaution should be taken with punarés during laboratory manipulations. The animals of both species, as well as other echimyid rodents, have very fragile skin and the tail may be ruptured when tensioned. Therefore we do not recommend manipulating them with forceps or handling them by the tail. We usually fix the neck of an animal with index and middle fingers and then hold the body with thumb and fourth finger. The animals rarely try to bite, but it is necessary to use thick rubber gloves during manipulation.

Blood sampling - We tried several methods of blood collection in punarés. The best results were achieved by intracardiac blood sampling. The animals were anesthetized with intramuscular injection of ketamine at the dose $100 \mathrm{mg} / \mathrm{kg}$. They displayed a great individual variability in their reaction to the same dose of ketamine. It seems that $T$. a. laurentius was more sensitive to the anesthetic effect of this drug than T. pachyurus because they tended to be anesthetized more quickly than T. pachyurus (personal observation). The anesthetized animals were fixed, the skin was sterilized and the blood was collected with $5 \mathrm{ml}$ syringe. Up to $2 \mathrm{ml}$ blood can be collected without any serious damage to the animal.

Blood collection from the retrobulbar plexus was less time consuming, although less effective in terms of the quantity of blood collected (no more than $1 \mathrm{ml}$ ). The procedure was carried out under local anesthesia with colirium ( $0.5 \%$ solution of proximetacaine cloridrate).

We do not recommend the collection of blood from the femoral vein. In punare it is very sensitive and hard to stop the bleeding. As we mentioned above punare tails are very fragile and for this reason we do not recommend blood collection from the caudal vein. However, small blood samples for serological and molecular genetic analyses can be taken from the tail tip.

Breeding - Breeding punarés in captivity was relatively simple. The breeding pairs rarely displayed agonistic behavior. We detected physical confrontation in only $2 \%$ of mating pairs of T. a. laurentius and $6 \%$ of T. pachyurus.

Average breeding success was the same in T. pachyurus and T. a. laurentius $\left(\chi^{2}=0.03 ; \mathrm{df}=1 ; \mathrm{p}=0.866\right)$ (Table). In pairs with less than two years, success reached $40-50 \%$, and gradually decreased after the second year of reproduction. Both colonies produced offspring throughout the year and did not show any reproductive seasonality.

TABLE

Reproductive traits in captive breed colonies of Thrichomys apereoides laurentius and Thrichomys pachyurus

\begin{tabular}{lcc}
\hline Species & T. a. laurentius & T. pachyurus \\
\hline Breeding success (\%) & $28,0+5,2^{a}$ & $27,7 \pm 6,6$ \\
Litter size at birth (g) & $3.4 \pm 1.3^{a}$ & $2.5 \pm 0.9$ \\
Body mass at birth, females (g) & $0.5 \pm 4.4^{a}$ & $29.3 \pm 5.7^{b}$ \\
Body mass at birth, males (g) & $20.2 \pm 3.8^{a}$ & $34.8 \pm 5.2$ \\
Body mass at weaning, females (g) & $58.4 \pm 8.6^{a}$ & $85.8 \pm 10.9^{b}$ \\
Body mass at weaning, males (g) & $61.0 \pm 11.3^{a}$ & $98.4 \pm 7.9$ \\
Postnatal mortality (\%) & $4.2 \pm 2.4^{a}$ & $18.2 \pm 6.8$ \\
Age of sexual maturation (day) & $40.2 \pm 14.5^{a}$ & $55.8 \pm 27.6$ \\
Mass at sexual maturation (g) & $94.4 \pm 22.2^{a}$ & $141.2 \pm 41.6$
\end{tabular}

$a$ : difference between the species is significant $(\mathrm{p}<0.05) ; b$ : sex difference is significant $(\mathrm{p}<0.05)$ 
Litter size and body mass - Mean litter size was significantly higher in $T$. a. laurentius colony than in $T$. pachyurus $(t=2.19 ; \mathrm{df}=32 ; \mathrm{p}=0.035)$ (Table). The litter size variation in $T$. a. laurentius (range: 1-6) was similar to that described by Roberts et al. (1988) for captive breed colony of punaré derived from Northeastern Brazil. $T$. pachyurus displayed a narrower range of variation (from 1 to 4). Sex ratio at birth did not differ from the expected $1: 1$ ratio in both species (T. pachyurus: $\chi^{2}=14.3 ; \mathrm{df}=20$; $\mathrm{p}>0.05$, T. a. laurentius: $\chi^{2}=16.7 ; \mathrm{df}=10 ; \mathrm{p}>0.05$ ). Postnatal mortality was the same in T. pachyurus and T. $a$. laurentius $\left(\chi^{2}=3.14 ; \mathrm{df}=1 ; \mathrm{p}=0.08\right)$ (Table).

Sex difference in body mass at birth and at weaning was not significant in $T$. a. laurentius $(t=0.24 ; \mathrm{df}=74 ; \mathrm{p}$ $=0.810, t=1.13 ; \mathrm{df}=77 ; \mathrm{p}=0.262$, respectively). In $T$. pachyurus this difference was significant and the males tended to be larger than females $(t=2.31 ; \mathrm{df}=19 ; \mathrm{p}=$ $0.032, t=2.28 ; \mathrm{df}=10 ; \mathrm{p}=0.045$, respectively). Average body mass at birth and at weaning was higher in $T$. pachyurus than in $T$. a. laurentius $(t=10.54 ; \mathrm{df}=95 ; \mathrm{p}=$ $0.0012 \times 10^{-14}$ and $t=10.18 ; \mathrm{df}=89 ; \mathrm{p}=0.0013 \times 10^{-13}$, respectively) (Table).

Development - There was a significant difference between the species in the age and body mass at sexual maturation $(\mathrm{t}=3,28 ; \mathrm{df}=66 ; \mathrm{p}=0,00168, \mathrm{t}=6,328 ; \mathrm{df}$ $=65 ; \mathrm{p}<0,0026 \times 10^{-5}$, respectively). Females of T. $a$. laurentius reached sexual maturation at six weeks and $T$. pachyurus two weeks later (Table).

The gestation period was estimated in one female of $T$. pachyurus (105 days) and five females of $T$. a. laurentius (95.4 \pm 1.4 days). This is in good accordance with the data of Roberts et al. (1988). Newborns of both species were precocious and had their eyes and ears open, teeth erupted, fur well developed and were able to eat solid food in the first week of life.

Up to the moment of writing this paper the oldest captive born specimens of T. pachyurus are 4 years old and those of T. a. laurentius are 5 years old.

\section{DISCUSSION}

Both species of Thrichomys meet all requirements to become suitable laboratory animal models for the study of parasitic diseases. They can be easily maintained in standard laboratory conditions and breed throughout the year. Illness such as viral infections and diarrhoea were never observed. They do not have any special dietary demands and can be fed by standard food pellets designed for laboratory mice.

The breeding colonies of Thrichomys may serve as an adequate model to study various aspects of the transmission cycle of $T$. cruzi, such as analyses of immune response dynamics to different $T$. cruzi isolates, tissue specificity of the parasite, and patterns of infection. It is worth mentioning that these animals are able to control the number of circulating parasites and maintain the infection with both $T$. cruzi I and T. cruzi II subpopulations, with hardly any mortality (Herrera et al. 2004b, Roque et al. 2005). Their very long gestation time (more than 3 months) permits studies in transplacental transmission of T. cruzi.
Thrichomys is a natural host of helminths of the genus Trichuris Roederer, 1761. Some species of this genus infect humans and cause immune suppression (Wick-elgreen 2004). Breeding colonies of Thrichomys have recently been used to establish the biological cycle of Trichuris sp. in the laboratory (Maldonado Jr A, pers. commun.).

The potential use of this model is not restricted by parasitological studies. Till now the researchers had at hand only one precocious laboratory animal - the guinea pig. Thrichomys may serve as an alternative model to study physiology, developmental, behavioural and reproductive biology of precocious species.

It is especially useful to have colonies of two different species which are able to produce viable hybrids because it presents opportunities for comparative and genetic analyses of various biological traits and processes.

The use of these captive breed colonies as models in parasitological and genetic studies has already produced encouraging results (Roque et al. 2002, Herrera et al. 2004b).

\section{ACKNOWLEDGMENTS}

To DL de Souza for technical assistance and laboratory staff for helping the animal maintenance.

\section{REFERENCES}

Alho CJ 1982. Brazilian rodents: their habitats and habits. In MA Mares, HH Genoways (eds), Mammalian Biology in South America, Linesville, Pittsburgh, p. 143-166.

Belal US, Norose K, Aosai F, Mun HS, Ahmed AK, Chen M, Mohamed RM, Piao LX, Iwakura Y, Yano A 2004. Evaluation of the effects of sulfamethoxazole on Toxoplasma gondii loads and stage conversion in IFN-gamma knockout mice using QC-PCR. Microbiol Immunol 48: 185-193.

Bogdanovich S, Perkins KJ, Krag TO, Khurana TS 2004. Therapeutics for Duchenne muscular dystrophy: current approaches and future directions. J Mol Med 82: 102-115.

Bonvicino CR, Otazu IB, D'Andrea PS 2002. Karyologic evidence of diversification of the genus Thrichomys (Rodentia, Echimyidae). Cytogenet Genome Res 97: 200-204.

Briones RSM, Souto RP, Stolf BS, Zingales B 1999. The evolution of two Trypanosoma cruzi subgroups inferred from rRNA genes can be correlated with the interchange of American mammalian faunas in the Cenozoic and has implica-tions to pathogenicity and host specificity. Mol Biochem Parasitol 104: 219-232.

D'Andrea PS, Horta C, Cerqueira R, Rey L 1996. Breeding of the water rat (Nectomys squamipes) in the laboratory. Lab Anim 30: 369-376.

Garzoni LR, Waghabi MC, Baptista MM, de Castro SL, Meirelles MN, Britto CC, Docampo R, Oldfield E, Urbina JA 2004. Antiparasitic activity of risedronate in a murine model of acute Chagas' disease. Int J Antimicrob Agents 23: 286-290.

Gonzalez EM, Claramunt S 2000. Behaviors of captive shorttailed opossums, Monodelphis dimidiata (Wagner, 1847) (Didelphimorphia, Didelphidae). Mammalia 64: 271-285.

Herrera HM, Dávila AMR, Norek A, Abreu UG, Souza SS, D'Andrea PS, Jansen AM 2004a. Trypanosoma evansi enzootiology in Pantanal, Brazil. Vet Parasitol 125: 263-275.

Herrera L, D'Andrea PS, Xavier SCC, Mangia RH, Fernandes O, Jansen AM. 2005. Trypanosoma cruzi infection in wild 
mammals of the National Park "Serra da Capivara", and its surroundings (Piauí, Brazil), endemic for Chagas disease. Trans R Soc Trop Med Hyg 99: 379-388.

Herrera L, Xavier SC, Viegas C, Martinez C, Cotias PM, Carrasco H, Urdaneta-Morales S, Jansen AM 2004b. Trypanosoma cruzi in a caviomorph rodent: parasitological and pathological features of the experimental infection of Thrichomys apereoides (Rodentia, Echimyiodae). Exp Parasitol 107: 78-88.

Hingst ED, D'Andrea PS, Cerqueira R 1998. Breeding of Philander opossum (Didelphimorphia: Didelphidae) in captivity. Lab Animals 32: 434-438.

Kumar T, Stanley VA, Lal AA, Balasubramanian M, Pillai KS 2002. Biochemical evaluation of multiple herbal treatments in alloxan-induced diabetes in Wistar rats. $J$ Environ Biol 23: 407-410.

Magalhães-Santos IF, Souza MM, Lima CSC, Andrade SG 2004. Infection of Calomys callosus (Rodentia Cricetidae) with strains of different Trypanosoma cruzi biodemes: pathogenicity, histotropism, and fibrosis induction. Mem Inst Oswaldo Cruz 99: 407-413.

Neiva A, Penna B 1916. Viagem científica pelo norte da Bahia, sudoeste de Pernambuco, sul do Piahuí e norte e sul de Goiaz. Mem Inst Oswaldo Cruz 8: 74-224.
Pessôa LM, Corrêa MMO, Oliveira JA, Lopes MOG 2004. Karyological and morphometric variation in the genus Thrichomys (Rodentia: Echimyidae). Mamm Biol 69: 258-269.

Roberts MS, Thompson KV, Cranford JA 1988. Reproduction and growth in captive punaré (Thricomys apereoides Rodentia: Echimyidae) of the Brazilian Caatinga with reference to the reproductive strategies of the Echimyidae. J Mammal 69: 542-551.

Roque ALR, Legey AP, Vitorino M, D'Andrea PS, Jansen AM 2002. Trypanosoma cruzi e Thrichomys apereoides (Rodentia, Echimyidae): a parasitologia como ferramenta no estudo da medicina ambiental. Rev Bras Med Vet 24: 148-150.

Roque ALR, D'Andrea PS, Andrade GB, Jansen AM 2005. Trypanosoma cruzi in the caviomorph rodents Thrichomys apereoides laurentius and Thrichomys pachyurus (Rodentia, Echimyidae): distinct patterns of infection in sibling species. Exp Parasitol 111:37-46.

Streilen KE 1982. Ecology of small mammals in the semiarid Brazilian Caatinga. I. Climate and faunal composition. Ann Carnegie Mus 51: 79-106.

Wickelgren I 2004. Can worms tame the immune system? Science 305: 170-171. 